\title{
KETERLIBATAN STAF PERAWAT UNTUK MENINGKATKAN KESELAMATAN PASIEN TERHADAP ALARM KLINIS PERANGKAT MEDIS DI RUMAH SAKIT AWAL BROS BATAM
}

\author{
Yulianti Wulandari ${ }^{1}$, Mulyana $^{2}$, Muhammad Putra Hidayat $^{3}$ \\ ${ }^{1,2,3)}$ STIKes Awal Bros Batam \\ email:Wwoelan@gmail.com, ana.mulyanastikesawalbros@gmail.com,Putrahidayat22092000@gmail.com
}

\begin{abstract}
Abstrak
Insiden cedera merupakan salah satu mutu dari pelayanan mutu keperawatan. Insiden cedera menunjukan kualitas pelayanan suatu rumah sakit dan memberikan dampak terhadap pasien, keluarga dan petugas yang merawat. Alarm klinis merupakan suatu alat yang digunakan untuk memonitoring keadaan dari berbagai pasien yang harus di lakukan oleh perawat. Beberapa pasien memerlukan pemantauan berlanjut dengn memantau aktifitas sehari -hari. Oleh karena itu, penting nya perawat terlibat dalam memonitor alarm klinis pasien untuk memudahkn dalam memantau beberapa keadaan pasien. Perawat harus mengetahui terlebih dahulu parameter pada layar alarm klinis pasien serta cara pemasangan alarm klinis pasien, sehingga dapat menghindari terjadinya insiden cedera fisiologis pada pasien. Manfaat dilakukannya pengabdian masyarakt ini agar untuk meningkatkan mutu dari pelayanan keperawatan serta mengurangi jumlah insiden terjadinya kecelakaan kerja di rumah sakit. Tujuan dari dilakukan pengabdian masyarakat ini untuk langsung menjelaskan keterlibatan perawat dalam meningkatkan keselamatan pasien terhadap alarm klinis perangkat medis di Rumah Sakit Awal Bros Batam
\end{abstract}

Kata Kunci : Alarm Klinis, Keselamatan Pasien

\begin{abstract}
The incidence of injury is one of the qualities of quality nursing service. The incidence of injury shows the quality of service in a hospital and has an impact on patients, families and carers. Clinical alarm is a tool used to monitor the condition of various patients that must be done by nurses. Some patients require continued monitoring by monitoring daily activities. Therefore, it is important that the nurse is involved in monitoring the patient's clinical alarm to make it easier to monitor the patient's multiple circumstances. Nurses must know in advance the parameters on the patient's clinical alarm screen and how to install the patient's clinical alarm, so as to avoid incidents of physiological injury to the patient. The benefit of this community service is to improve the quality of nursing services and reduce the number of incidents of work accidents in the hospital. The purpose of this community service is to directly explain the involvement of nurses in improving patient safety against clinical alarms of medical devices at Awal Bros Hospital Batam.
\end{abstract}

Keywords: Clinical Alarm, Patient Safety

\section{PENDAHULUAN}

Insiden cedera tekan merupakan salahsatu indikator mutu dalam bidang pelayanan keperawatan. Insiden cedera tekan menjadisalah satu tolak ukur efektifitas keselamatan pasien untuk terselenggaranya pelayanan kesehatan yang aman dan efektif (Kemenkes.RI, 2016). Pasien Monitor digunakan untuk memonitor beberapa parameter kesehatan pasien secara non invasive yang membutuhkan pemantauan berlanjut dalam jangka waktu tertentu. Pada umumnya Pasien Monitor terdapat limaParameter yaitu : Saturasi Oksigen (SPO2),Respirasi, EKG, BPM, dan Suhu Tubuh.

Pada rumah sakit di mana sebagian besar pasien yang kondisi fisiknya harus sering di pantau sebagai suatu bagian dari prosedur diagnostik, kebutuhan akan tindakan yang efektif dan cepat dalam menanggapi mekanisme peringatan tidak bisa dihindari. Suatu system atau peralatan yang tepat dapat membantu staf perawat dalam mengetahui alarm klinis pada pasien. Sehingga keselamatan pasien tetap terjaga. 
Berdasarkan hal tersebut, pengabdian masyarakat ini dilakukan bertujuan untuk melakukan langsung menjelaskan keterlibatan perawat dalam meningkatkan keselamatan pasien terhadap alarm klinis perangkat medis di Rumah Sakit Awal Bros Batam.

\section{METODE}

Adapun sasaran dalam kegiatan pengabdian masyarakat ini adalah staf perawat Rumah Sakit Awal Bros Batam. Metode yang digunakan dalam kegiatan penyuluhan dilakukan dengan tiga macam, yaitu : metode ceramah, diskusi, tanya jawab dan praktik alaram klinis. Kegiatan ini di awali dengan pengenalan dari patient monitor sebagai alarm klinis pasien.

\section{HASIL DAN PEMBAHASAN}

1. Tahap persiapan

Melakukan koordinasi dengan diklat Rumah Sakit Awal Bros Batam yang dilakukan pada tanggal 13 Oktober 2020 dari hasil koordinasi tersebut disepakati untuk melakukan kegiatan sosialisasi dengan staf perawat Rumah Sakit Awal Bros Batam.

2. Tahap Implementasi

Pelaksanaan kegiatan ini dilaksanakan pada 15 Oktober 2020, dengan melibatkan staf perawat Rumah Sakit Awal Bros Batam. Dengan di ikuti 20 perawat. Saat penyampaian materi peserta mampu mengulang kembali materi yang di sampaikan, perawat sangat interaktif selama kegiatan berlangsung.

3. Tahap Evaluasi

Evaluasi dari kegiatan ini dilakukan dengan mendemokan cara menggunakan patient monitor sebagai alarm klinis untuk keselamatan pasien dan peserta mencoba satu persatu.
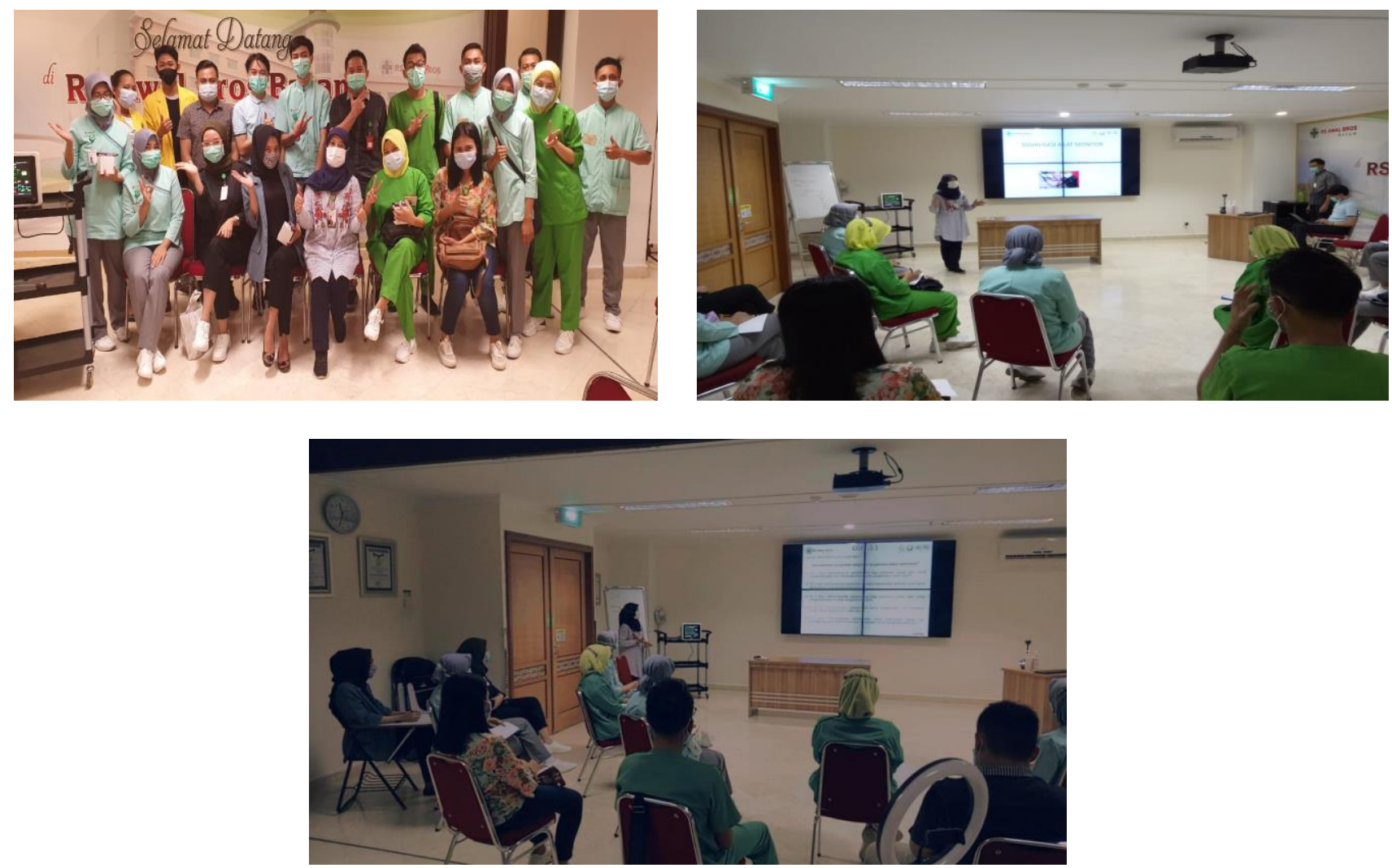

Gambar 1. Kegiatan Sosialisasi Alarm klinis pasien dengan perawat 


\section{SIMPULAN}

Kesimpulan dari pengabdian masyarakat ini adalah bahwa pentingnya keterlibatan langsung perawat dalam meningkatkan keselamatan pasien dengan cara mengetahui lebih lanjut alarm klinis pasien. Dimana sebagai bentuk untuk meningkatkan indicator mutu Rumah Sakit.

\section{UCAPAN TERIMA KASIH}

Ucapan terima kasih penulis sampaikan kepada Diklat Rumah Sakit Awal Bros Batam dan seluruh perawat RS Awal Bros Batam yang turut menjadi responden.

\section{DAFTAR PUSTAKA}

Bowles, K., H., Dykes, P., \& Demiris, G.(2015). The use of health informationtechnology to improve care andoutcomes for older adults.HHSPublic Access,8(1), 5-10.https://doi.org/10.3928/1940492120121222-01

Creehan, S. (2015). Building nursing unitstaff champion programs to improveclinical outcomes.Nurse Leader,13(4), 31-35.https://doi.org/10.1016/j.mnl.2015.06.001

Herman, Irving P. 2007.Physics Of HumanBody. Berlin: Springer

Kemenkes.RI. (2016). Kamus indikatorkinerja badan layanan umum unitpelaksana teknis vertikal.

Jakarta. 